\section{W pończosze istota jest... Rozmowa z Karoliną Wiktor}

Klaudia Muca, Karolina Wiktor

TEKSTY DRUGIE 2016, NR 5, S. 404-426

DOI: $10.18318 /$ td.2016.5.26

Klaudia Muca: Czym jest zamknięcie w afazji? Często zwracasz uwagę właśnie na problem zamknięcia.

Karolina Wiktor: Absolutną niemożnością komunikacji ze światem. W afazji wszystkie kody komunikacji zostają zerwane, a zatem naturalną konsekwencją zamknięcia jest to, że zostajesz sam ze swoją myślą. To zamknięcie fizyczne, psychiczne, mentalne. Trzeba mieć dużo samoświadomości, żeby z niego wyjść. Wielu Afazjan myśli w ten sposób: skoro nagle stałem się osobą niepełnosprawną, to już tak zostanę; zapominają o tym, że pewne umiejętności można wyćwiczyć i - dajmy na to - za trzy miesiące być w miarę sprawnym człowiekiem, który "coś" komunikuje. Jeżeli np. mądry lekarz lub terapeuta nie wytłumaczy ci tego, to zostajesz w zamknięciu sam. Afazja w powszechnej świadomości jest bardzo słabo obecna.
Klaudia Muca - doktorantka na Wydziale Polonistyki UJ. Zainteresowania badawcze: reprezentacje niepełnosprawności w kulturze, literatura współczesna, krytyka literacka. Pracuje w redakcji „Fragile" i w Instytucie Książki w Krakowie. Kontakt: klaudia.muca23@ gmail.com.

\section{Karolina Wiktor -} artystka wizualna, w latach 2001-2013 tworzyła razem z A. Kubiak duet performerski Grupa Sędzia Główny. W 2009 r. w wyniku pęknięcia tętniaka i dwóch udarów nastąpił całkowity zwrot w jej karierze. Swoje doświadczenia opisała w książce Wołga przez Afazję. Obecnie zajmuje się poezją wizualną oraz tworzeniem cyklu konferencji i warsztatów „Kultura i Neuronauka" w Zachęcie Narodowej Galerii Sztuki. 
Afazja - mówiłam o tym na TEDxie ${ }^{1}$, a także na konferencji² - to dysfunkcja intelektu. To nie jest choroba, to dysfunkcja intelektu spowodowana uszkodzeniem mózgu - może to być wylew, czyli udar krwotoczny lub udar niedokrwienny (zawał mózgu), ale też uderzenie głowy podczas wypadku samochodowego. To tak naprawdę wynik zrządzenia losu lub nieszczęśliwego upadku.

\section{Kiedy doznałaś udaru, w wyniku którego doszło do afazji? Jak się dzisiaj czujesz?}

Krwawienie podpajęczynówkowe z pękniętego tętniaka lewej tętnicy kręgowej, czyli wylew krwi do mózgu, lub - jak kto woli - udar krwotoczny zaczął się 28 sierpnia 2009 roku. Po totalnej embolizacji tętniaka³, którą przeprowadzono 1 września, siódmego dnia tego miesiąca nastąpił drugi udar z tą różnica, że był to udar niedokrwienny z niedowładem połowicznym prawostronnym i afazją sensoryczną. Dziś jestem sześcioletnim mańkutem, czasem drewnianym, a czasem próbującym ubarwić rozmowę składnią języka z nieznanego kraju Afazji. Biegnę w zdrowiu z myślą o dalszym rozwoju (śmiech).

\section{W jednym z tekstów poświęconych afazji - tekście lingwisty, Romana Ja- kobsona - mówi się o niej jako o regresie. Zgadzasz się, że afazja to rodzaj regresu?}

W tym lingwistycznym kontekście absolutnie tak, to jest regres. Nagle wracamy do punktu wyjścia, czyli dnia urodzenia, w którym np. ja znalazłam się ponad trzydzieści lat temu. Trzeba pamiętać, że są różne afazje - motoryczna, sensoryczna, mieszana (tę ja miałam). Korzeń istotności w tym wszystkim jest taki: każda z nich to faktycznie dysfunkcja intelektu, czyli regres w pewien sposób.

\section{Ale jednak odwracalny, wektor zmiany można skierować w drugą stronę, prawda?}

1 Wołga przez Afazję... kilka kroków dalej: Karolina Wiktor at TEDxWarsawWomen 2013, https:// www.youtube.com/watch?v=XdHoesFiEXk (1.09.2016).

2 Chodzi o konferencję Kultura i Neuronauka, która odbyła się 25 października 2014 roku w Warszawie. Więcej informacji można znaleźć na stronie internetowej projektu: http://afazja.blogspot.com/ (1.09.2016).

3 Embolizacja polega na zabezpieczeniu tętniaka przez zamknięcie światła chorobowo zmienionych naczyń krwionośnych - przyp. red. 
Dokładnie tak. I to właśnie odróżnia afazję od innych niepełnosprawności neurologicznych. Każdy przypadek ma własne, odmienne cechy i wszystko zależy od tego, jak wielki był ubytek, jak mocny był udar lub w którym miejscu pojawił się i jak duży był tętniak. Bardzo często pewne zdolności i umiejętności można bardzo szybko wyćwiczyć. Regres... Owszem, Jakobson ma dużo racji, tylko że on nie pochodził z Afazji - on pochodził z realu i rozumował jak zdrowy naukowiec, a afazja jest bardzo subiektywną, indywidualną sytuacją niesprawności, w której wiele spraw wyklucza się nawzajem, niestety. Pewne jest to, że regres nie dotyka sfery emocjonalnej - wręcz przeciwnie, rozwija sferę emocjonalną ponad miarę - i za to też odpowiada nasz mózg.

Mózg jest naszym najważniejszym mięśniem, o czym często mówię, choć wielu twierdzi, że tak nie jest, ale ja tak uważam (śmiech). Jestem dowodem na to, że owszem, afazja jest regresem, ale bardzo szybko można zlikwidować jej skutki, usprawnić to, co nie działa - właśnie ze względu na to, że afazja związana jest z mózgiem. Gdyby to był regres w przypadku nogi i już nigdy nie mogłabym być sprinterem - to byłaby nieodwracalna dysfunkcja. Ale jeśli weźmiemy pod uwagę nasz mózg, który jest plastyczny i ma możliwości rekompensacyjne, to Jakobson nie miał racji.

\section{Mam wrażenie, że w literaturze przedmiotu podchodzi się do afazji trochę instrumentalnie. Istnieje też książka Henriego Bergsona Materia i pamięć. O stosunku ciała do ducha, w której filozof posłużył się różnymi świadectwa- mi afazji po to, by uzasadnić swoje filozoficzne dzieło, znaleźć jakiś punkt wyjścia, po którym w książce nie ma prawie śladu.}

Nie wiem, czy zauważyłaś, że wiele osób, które opisują afazję, mówi o zjawisku, niedostatecznie interesując się samym człowiekiem, a afazja jest związana z człowiekiem, nie z jego nogą, tylko z jego jestestwem. Afazja to nie tylko niemożność mówienia. Wszyscy w ten czy inny sposób możemy się komunikować, nawet jeśli mamy ogromne ubytki z powodu rozległego wylewu. Tak naprawdę problem dotyczy funkcji poznawczych, motorycznych, wszystkiego, czym jesteśmy jako człowiek, a nie jako jednostka chorobowa. Pamiętam, że w szpitalu, po trzech miesiącach od wylewu, jak już się obudziłam i zrozumiałam, że jestem w "czarnej dupie” - tak, to była "czarna dupa”, to nie była choroba, tylko „czarna dupa”, w której nie jesteś w stanie zrozumieć nic - nikt mi np. nie powiedział: słuchaj, Karolina, jeśli będziesz się starać, to wrócisz do pewnego poziomu intelektualnego. Wylew i udar „ucięły” mi wiele funkcji myślowych, ale okazało się, że pozostała cała sfera emocjonalna. Ta sfera była zupełnie przeze mnie niedoceniana, nie wiedziałam, że jest tak 
bardzo rozbudowana. Nasz mózg ma ogromny potencjał, a wielu naukowców zupełnie o tym nie pamięta. Moim zdaniem ograniczanie nas tylko i wyłącznie do funkcji biologicznych jest wypaczeniem.

\section{Pamiętasz jeszcze ten moment, kiedy zdecydowałaś się na prowadzenie bloga, a potem na wydanie książki Wołga przez Afazję? Jakie emocje Ci to- warzyszyły? Czy to był impuls, czy zaplanowane działanie?}

Tak, to było zaplanowane działanie. W pewnym momencie pomyślałam sobie, że nie jest ze mną aż tak źle. Zauważyłam swoje postępy. Okazało się, że im więcej ćwiczę fizycznie, tym lepiej mówię. Mało tego, im więcej ćwiczę, tym lepiej działa moja wyobraźnia, moje funkcje poznawcze zaczęły być w dobrej komitywie z innymi obwodami rzeczywistości. Pomyślałam, żeby zrobić coś, aby ta rehabilitacja przebiegała szybciej. Skoro cały czas robię ćwiczenia logopedyczne, to można przełożyć to na coś, co będzie tylko moje. Wcześniej zajmowałam się sztuką i to dzięki niej nie bałam się niesprawności, ale również przekraczania granic. Sztuka to po prostu kawałek wolnej przestrzeni, w której nic cię nie ogranicza, tam nie ma żadnego deficytu, tam po prostu jest wyobraźnia i tam mogę jeździć ultramarynową wołgą bez prawa jazdy. A może zrobię blog? Pamiętam, był marzec i byłam po prostu zachwycona tą myślą. Spotkałam się z moją logopedką - Małgosią Wysocką - która nota bene pochodzi z Krakowa - i cudowna Małgosia mówi: super pomysł, zrób to! Przyszła do mnie też któregoś razu i mówi: mam kolorowe kredki do pisania, a nie tylko czarny ołówek. Yhmmm, no to fajnie... - pomyślałam. Dało mi to oddech z „czarnej dupy”, a afazja nabrała koloru.

Samo pisanie to jedna rzecz, ale przecież musiałam zarejestrować blog, stworzyć grafikę. Trzeba pamiętać, że moje funkcje poznawcze były wtedy bardzo ograniczone. Blog wymyśliłam w marcu, a pierwszy post to chyba 24 kwietnia - prawie dwa miesiące zabrało mi, żebym mogła nacisnąć start. To było dla mnie bardzo, bardzo męczące, a jednocześnie zupełnie nie chciałam epatować swoją niemożnością, tym, że nie potrafię pisać; nie chciałam zaczynać od logopedycznych obrazków, pierwszych liter - wydało mi się to zbędnym komunikatem. Dopiero później zaczęłam się nimi bawić, są w książce i na mojej wystawie.
Ale z drugiej strony, w tym opisywaniu niemożności jest twoja własna ko- rzyść: potrafiłaś wyrazić to, że nie możesz, i to już jest sygnał, że jednak... ... mogę. Dlatego chciałam jeździć ultramarynową wołgą po Afazji, a nie po ćwiczeniach logopedycznych. Clou tej sytuacji było zupełnie inne. Tu nie 
chodziło o medyczną informację, tylko o artystyczną wrażliwość tekstu i sytuacji niepełnosprawności. My, Afazjanie, przez to, że nie możemy komunikować się tak, jakbyśmy chcieli, mamy bardziej rozwiniętą sferę wrażliwości - trochę tak, jak ludzie, którzy nie widzą albo nie słyszą, nagle dotykają w szczególny sposób, mają taki inny „słuch”.

My bardziej czujemy, niż wiemy. I niesamowite jest to, jak wszystko jest skorelowane z rzeczywistością. Siedzisz i zaczynasz sobie wyobrażać, co tam jeszcze może być... Wyobraźnia pozostała na miejscu, wybuchy mózgu wcale nie zmiotły wszystkiego. Oprócz wyobraźni została też empatia i cała sfera emocjonalna, a skoro przeżyłam, to mogę coś z tym zrobić. Na początku blog to była moja własna rehabilitacja. Ja po prostu chciałam pisać, rehabilitować się logopedycznie, a jednocześnie udowadniać sobie, że mogę przejechać wołgą od jednego przystanku do kolejnego. Tak naprawdę wyobraziłam sobie mapę. Zawsze mi się wydawało, że jestem wyobrażeniowym kartografem.

\section{Kartograf i korespondent (śmiech). W książce piszesz, że ta wyobrażona kraina, z której jako korespondent nadajesz specjalny komunikat, ma swoją własną, szczególną architekturę. Opowiesz, z jakich elementów budowałaś tę krainę?}

Z jednej strony z tego, co czuję jako artystka, z drugiej, z tego, czego doświadczam jako niepełnosprawna osoba. Czuję np. to, że boję się ludzi. My, Afazjanie, mamy duży problem z lękiem w ogóle. Wiele osób myśli, że boimy się ośmieszenia, ale tu chodzi o coś zupełnie innego. Nagle jesteś osobą niepełnosprawną z dysfunkcją intelektu, która powoduje, że nie jesteś w stanie przekazać tego, co myślisz lub chcesz, a chcesz po prostu szklankę wody albo np. Marlboro Light w miękkim opakowaniu - dlatego przestałam palić, ponieważ nagle uświadomiłam sobie, że pójdę do sklepu i powiem: hmmymmymy? Więc myślę sobie: no dobra, to chyba już w ogóle nie będę palić - i do dzisiaj nie palę. Ale do czego zmierzam - zapytałaś, z czego budowałam tę krainę. Z jednej strony z uczuć, odczuć, które są trochę wyobrażeniowe, nawet nadmiarowo wyobrażeniowe. My, Afazjanie, mamy np. duży problem z dźwiękami. Wychodzimy na ulicę, wszystkie dźwięki zbijają się w chaos, który jest nie do wytłumaczenia i nie do wytrzymania, to autostrady dźwięku. Więc z jednej strony opieram się na odczuciach i przemyśleniach o tym, jak się czuję, ale nie tylko jako ja - Karolina Wiktor - lecz także o tym, jak czuje się Afazjanin, a Afazjanin często ma duży problem z dźwiękami. Kolejna rzecz, im więcej osób mówi, tym mniej rozumiemy. Niestety, doświadczam tego do dzisiaj, kiedy np. jestem w jakiejś dużej przestrzeni i wszyscy zaczynają 
mówić, tworzy się komunikacyjny chaos nie do wytrzymania i przestaję rozumieć cokolwiek. Oprócz odczuć jest jeszcze analiza osoby. Celowo napisałam o sobie jako korespondent, ponieważ przyjechałam do Afazji przez przypadek i jako korespondent chcę wrócić do realu.

Właśnie tak o tym myślałam, że korespondent to ktoś, kto chce wrócić, kto jest na granicy między światem, z którego przyszedł, a światem, z którego nadaje jakiś komunikat.

Absolutnie. Dlatego właśnie nie bez kozery wymyśliłam jednocześnie paszporty Afazjanina, konferencję itd., żeby uświadomić łączność tych światów i niestety ich wzajemne niezrozumienie. Zaskakuje mnie, jak bardzo jedna i druga strona nie chcą wniknąć w sytuację obopólnej zależności. My, Afazjanie, zamykamy się w sobie, ponieważ wielu z nas ma problem z emocjami, bardzo się denerwujemy. Zresztą, jest taki przystanek w książce: Afazyjne emocje, czyli sceptycznie wkurwiona. Wybuchy dotykają mózgu, w którym są emocje. Do cholery jasnej, pamiętajcie też o tym! Czasem wyobrażam sobie te wybuchy; udar to rodzaj takiego leja w twojej głowie. Wszystko w tym leju i wokół niego obumiera i dlatego drogi komunikacji muszą zostać utworzone na nowo. Bardzo często to się udaje, ale czasem te drogi tworzą się długo, ponieważ są np. ... kręte i głębokie (śmiech).

Pamiętasz, było takie super opowiadanie Lema, oczywiście nie pamiętam tytułu, jak to mam w zwyczaju - nowa uroda niepamięci. To opowiadanie, w którym naukowiec opiekuje się siedmioma czy ośmioma lejami i każdy ten lej ma swoją własną świadomość $c^{4}$. Jeden jest świadomością kobiety, drugi lej ma świadomość jakiegoś badacza itd. Naukowiec dogląda tych lejów, podlewa je, robi z nimi wiele rzeczy i komunikuje wyniki badań innym naukowcom. Jest jeden lej, który jest świadomy, że jest człowiekiem w leju, i kim jest? Jest teoretycznie szaleńcem, czyli ma problem z czym? Z mózgiem, czyż nie? W każdym leju w środku był człowiek i każdy miał swoje życie, tylko że to życie to był lej. I tylko jeden człowiek mówi: halo, jestem w leju, nie mogę już tu być, chcę stąd wyjść!

Kiedy ten człowiek uświadamia sobie, że jest w leju i przez to jest ograniczony, to jest pierwszy krok do tego, żeby wyjść z zamknięcia. Jest zupełnie tak, jak z Twoim pierwszym wpisem na blogu.

4 Chodzi o opowiadanie z cyklu Ze wspomnień ljona Tichego, poświęcone profesorowi Corcoranowi. Zob. S. Lem Dzienniki gwiazdowe, Wydawnictwo Literackie, Kraków 1966, s. 213-228. 
Tak, właśnie tak. Tylko co mogę zrobić, żeby wyjść? Przejechać wszystkie przystanki Afazji, które sobie wyobraziłam. Nie wiem, czy wszystkie przejadę, ponieważ nie wiem, które będą istotne, a które nie. Po prostu intuicyjnie je odwiedzam, nie tylko dlatego, że jestem przeświadczona o prawdziwości tych przystanków. Nie mam zielonego pojęcia, co tam będzie, ponieważ przecież nigdy nie byłam w Afazji, ale jednocześnie mam dużą przyjemność podróży - tak naprawdę podróży w głąb siebie. I to jest niesamowicie „mięsiste" doświadczenie.

\section{Pamiętasz ten moment, kiedy zdecydowałaś się przenieść wpisy blogowe do książki i je wydać?}

Pamiętam. Nie było to takie oczywiste. W pewnym momencie odezwał się do mnie Artur Żmijewski, który chciał stworzyć coś na kształt mojego wykładu. Wtedy nie mogłam jeszcze mówić, więc się nie zdecydowałam, na co on mi powiedział: dobrze, to porozmawiajmy przez Internet. W trakcie naszej rozmowy zaproponował, żebym zrobiła coś na Biennale w Berlinie. Pomyślałam o zrobieniu papierowego przewodnika po afazji, który możesz włożyć do kieszeni, miało to być wydane jako ulotka. Bardzo mi zależało na tym, żeby stworzyć zwykłą ulotkę bez żadnego hajpu, że jestem artystką i tworzę. Zresztą, książka Wołga przez Afazję ma także format, który możesz złożyć, skręcić i nosić przy sobie. Po tym wszystkim, co się wydarzyło, zupełnie odmieniło mi się rozumienie sztuki, a także rozumienie mnie jako człowieka. Nie potrzebuję być na szczycie wielkiego świata sztuki. Ważniejsze jest to, co naprawdę istotne, a nie to, czy ktoś o mnie napisze, czy nie napisze.

\section{Jak było z tą książką? Jakie były jej perypetie wydawnicze?}

Chcesz usłyszeć, jakim nieprzyzwoitym człowiekiem jest Artur Żmijewski? Możesz to też przeczytać w wywiadzie w „Krytyce Politycznej” i na moim blogu

\section{Sama wybierałaś i opracowywałaś wpisy, które znalazły się w książce?}

Sama. Początkowo książka wyglądała tak... [Karolina pokazuje roboczą wersję książki, wydrukowaną na papierze A4, zbindowaną.] To jest pierwsza wersja mojej książki. Potem została profesjonalnie opracowana przez dział wydawniczy Zachęty z Dorotą Karaszewską na czele i z Maciejem Sikorzakiem jako grafikiem DTP.

5 K. Wiktor, A. Żmijewski Pustka przerywana treściq , "Krytyka Polityczna” 2013 nr 31/32, s. 102-128. 


\section{Ta pierwsza wersja niewiele się różni od właściwej.}

Niewiele. Do tej pierwszej wersji nie zdążyłam jeszcze dołożyć pewnych elementów, nie ma np. Jesteś czarownikiem, jesteś wojownikiem, a bardzo mi na tym zależało. I tutaj jeszcze jest, widzisz, moja pierwotna wersja paszportu dla osób po udarze. Na początku zrobiłam taką wersję dla udarowców, żeby móc sama pojechać do Warszawy. I dałam to tacie. Mówię: tato, wypisz to. Tata zaczyna to czytać i mówi: co to jest? To jest taki mój niezbędnik. Oczywiście nie użyłam słowa "niezbędnik" albo jakiegoś innego, tylko powiedziałam: hyhmmmhm (śmiech). I on mówi: co ty chcesz dalej z tym zrobić? Pojechać do Warszawy. Wtedy pierwszy raz pojechałam sama do stolicy i to było coś.

WTwoim życiu pojawiły się więc dwa przełomy: wyjazd do Warszawy, wyjście ku innemu światu oraz ciąża, o której piszesz w Wołga przez Afazję w rozdziale ciąża w Afazji i jej emocje.

Ależ oczywiście! W książce piszę na samym końcu, że chodzę wokół takiego dużego jeziora - ponieważ faktycznie chodziłam wokół jeziora, którego wcześniej nie znałam. Wtedy uświadomiłam sobie, że to doświadczenie absolutnego duchowego przełomu, którego nie jesteś w stanie dokładnie opisać, opisujesz je kulawo, „drewnianie”, ale jednocześnie masz taki fun, bo wynajdywanie języka z kieszeni to niesamowite zajęcie.

Bawię się do dzisiaj językowymi przekręceniami, dlatego słownik afazyjny jest właśnie taki, jaki jest. Nietototanik - no przecież to nonsens (śmiech). Zawsze uwielbiałam poezję Bursy i Mirona Białoszewskiego, zawsze lubiłam też Peipera, Wata, Brzękowskiego i Czyżewskiego. Po wylewie okazało się, że co mogę czytać? Poezję, ponieważ jest krótka, ponieważ moja logika jest tak pokiereszowana i nastawiona na niuans, na nieoczywiste przejścia i wyjścia. Pamiętam, jak któregoś razu podarowałam pewnej kobiecie z Warszawy jeszcze niewydaną książkę i poprosiłam, żeby powiedziała mi coś na jej temat. I ona mówi: wiesz co, to takie krakowskie bardzo. - A co to znaczy krakowskie? - Taki futuryzm krakowski. (Zaznaczam, że jej emocje były bardzo negatywne.) - O jakie beznadziejne określenie, nawet jeżeli to będzie Pcim Dolny, to jakie to ma znaczenie? (śmiech) Uwielbiam futuryzm i jeśli jakiś zarzut wobec książki ma właśnie dotyczyć jej futurystyczności, to ja taki zarzut przyjmuję. Inspiruję się twórczością tych wszystkich poetów, ale czy tak naprawdę się inspiruję...? Ja tych poetów po prostu dobrze rozumiem.

Czytanie takich niuansów to niesamowita zdolność, każdy polonista by ci tego pozazdrościł (śmiech). To bardzo trudne. Poezję interpretuje się 
znacznie trudniej niż prozę, tak mi się wydaje. Przestrzeń możliwych znaczeń jest znacznie szersza.

Oczywiście. Po wylewie przestałam czytać prozę. Czasem sięgam po prozę futurystyczną. Czytam poezję, ponieważ jest mi łatwiej. Jeśli jestem w stanie przeczytać coś oprócz poezji, to są to książki o mózgu. $\mathrm{O}$, to jest właśnie ta książka, o której ci mówiłam [Karolina sięga po leżącą obok książkę dra Mateusza Hohola Wyjaśnić umyst]. Bardzo dobra.

Chciałabym jeszcze na chwilę wrócić do tworzenia nowego języka i nowej grafii, ponieważ w Wołgą przez Afazję powstają pewne układy znaków interpunkcyjnych. Zwykle takie znaki traktuje się jak coś przezroczystego, pozbawionego dodatkowego znaczenia poza funkcją delimitacyjną przypisaną im w systemie języka.

Tych znaków w jednym układzie jest cztery, choć czasami jeszcze więcej. Dlaczego? To są symboliczne przystanki myślowe i językowe, np.... [tu Karolina zaczyna szukać w książce odpowiedniego fragmentu] O, połówkowy Pinokio [zaczyna czytać]: „z nudów nicnierobienia lub dla uwiarygodnienia szczątków systematyczności - kreślę szlaczki”. W książce pojawia się długa linia i nagle okazuje się, że ten szlaczek ma znaczenie. Ten układ: kreska-kreska-mała kreska to właśnie taki przystanek, bardzo symboliczny moment.

Taki ślad niemożności, której doświadczałaś na początku... Absolutnie tak.

\section{Jaka jest rola obrazów i zdjęć w Twojej książce?}

W książce nie ma tak naprawdę zdjęć. Na końcu pojawia się jedno, które znalazłam przez przypadek, taką uśmiechniętą siatkę. A dlaczego? Zawsze bardzo mnie interesowała tkanka miejska, zawsze robiłam nieoczywiste zdjęcia tej tkanki, tak naprawdę dla swojej własnej przyjemności, ale jednocześnie dla swojego archiwum. Po wylewie okazało się, że tkanka miejska zaczęła być dla mnie jeszcze bardziej interesująca. Okazało się, że gdy idę na spacer, widzę nieoczywiste niuanse rzeczywistości, takie, które wcześniej wydawały mi się zupełnie nieistotne. Idę sama, nie rozmawiam z nikim, nie mam słuchawek na uszach, ponieważ jedno ucho mi trochę nie działa po wylewie, więc idę i robię zdjęcia nieoczywistościom. Te zdjęcia mają zawsze jakiś kontekst, np. tekstowy, ale również kontekst jakiegoś wizualu, takiego jak ultramarynowa wołga, którą po raz pierwszy zobaczyłam podczas wycieczki na Krym. 


\section{Obrazy w książce pochodzą też z drugiego twojego bloga, tego o poezji wizualnej.}

Tak, ale najpierw pojawiały się na blogu o afazji, obecnie to blog Kultura i Neuronauka. W pewnym momencie zaczęłam bawić się obrazem i im więcej rozumiałam, tym więcej czytałam, głównie poezji. Za każdym razem, kiedy cokolwiek zaczynałam pisać, jakikolwiek tekst, np. do centrum siebie, to najpierw w mojej wyobraźni pojawiał się obraz - do dzisiaj tak jest. Czasem przez zupełny przypadek stworzę jakąś „krzywą” nazwę, jak np. „usto”, albo tak jak na mojej wystawie, gdzie znajduje się tekst „bezmiejsca wszystkości”. To są tekstowe momenty, które fascynują mnie słowotwórczo, nie chcę z tego rezygnować.

Miałam podobny moment olśnienia, kiedy przeglądałam Twoje grafiki z bloga o poezji wizualnej. Na jednej z grafik pojawiło się sformułowanie „literowanie luk codzienności”, które wydało mi się trafionym w punkt określeniem procesu powracania do realu po afazji, a zarazem określeniem dynamiki tego procesu.

Też myślę, że to był wyjątkowy tekst, który stworzyłam przez przypadek, a może i świadomie, nie wiem. Pojawił się w kontekście pytania o Grupę Sędzia Główny. Zanim napisałam ten tekst, naprawdę bardzo długo myślałam o tym, co było wcześniej. Kiedy mnie zaczęto dopytywać, w jaki sposób dzisiaj patrzę na działalność Sędziego, to odpowiadałam, że to literowanie codzienności. Dzisiaj operuję głównie literą. Żeby zrozumieć, czym był Sędzia, muszę to przeliterować. A Sędzia to Ola Kubiak i Karolina Wiktor. Kierowałyśmy uwagę na niuanse, przyglądałyśmy się lukom, nieoczywistościom, temu wszystkiemu, co jest przemilczane. Bardzo często robiłyśmy perfo $^{6}$, żeby skłonić do myślenia o tym, o czym wy nie chcieliście myśleć. Dzisiaj robię zupełnie inną sztukę - przez literę. No i stąd takie przełożenie. To, że mój świat dzisiaj wygląda zupełnie inaczej, to, że performance się skończył, to wcale nie oznacza, że skończyło się literowanie luk codzienności; to literowanie istnieje, tylko używam do tego innych narzędzi i tematy również są nieco odmienne. Cała Wołga... taka właśnie jest. Chciałam wejść w afazję, aby uzyskać bardziej uniwersalne doświadczenie tego, jaka ona tak naprawdę jest poza historią medyczną, aby przeliterować tę lukę noworealu.

6 Chodzi oczywiście o sztukę performance - przyp. red. 


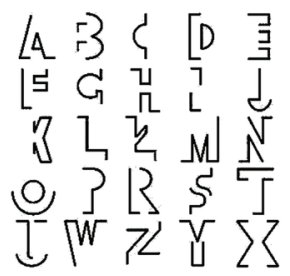

0[0 [0

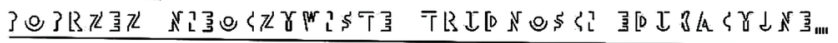

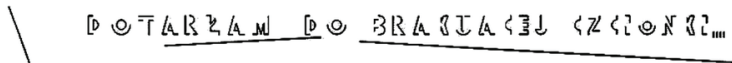

Pismo, pisanie, litery to jeden z podstawowych tematów w Twojej twórczości i jednocześnie podstawowe narzędzie twórcze. Zaprojektowałaś Alfabet brakującej czcionki, zaprezentowany po raz pierwszy na wystawie La déchirure. Rozdarcie w Atlasie Sztuki w Łodzi. Na czym polega ten artystyczny projekt i jak powstawał?

Wszystko zaczęło się od Wywiadu wizualnego, który zrobiłam razem z Łukaszem Musielakiem. Podczas promocji książki w Zielonej Górze u Wojtka Kozłowskiego w BWA Łukasz podszedł do mnie i mówi: słuchaj, Karolina, co myślisz o tym, żebyśmy zrobili wywiad do „Szumu”, ale taki jak twoja książka, wizualny wywiad. Bardzo mi się spodobał ten pomysł. Powiedziałam mu tak: prześlij mi te pytania, a ja pomyślę, jak to ugryźć wizualnie i oczywiście tekstowo. Pytania dotyczyły głównie książki, ale nie tylko. Przez to, że wcześniej zajmowałam się sztuką i działałam przez dziesięć lat jako performerka, to musiało pojawić się konkretne pytanie dotyczące sztuki czy Sędziego Głównego. Łukasz naprawdę wczytał się w książkę, dopytywał o niuanse, np. o to, którą literę lubię, albo czy w „czarnej dupie” są przyjemności - na to pytanie oczywiście odpowiedziałam: brak. W trakcie myślenia o tym wywiadzie i tworzenia go uświadomiłam sobie, że jestem kartografem, właściwie zawsze myślałam, że jestem kartografem, ale teraz jestem tego pewna (śmiech). Mało tego, powinnam studiować architekturę, a nie malarstwo, dlatego że widzę przestrzennie bardzo wiele rzeczy i rozplanowuję wiele spraw w przestrzeni. Jaka jest książka? No właśnie książka jest przestrzenna. Przechodzę z jednego przystanku do drugiego, jeżdżę wołgą i nagle się okazuje, że ten świat ma swoją architektonikę - to akurat nawiązanie do książki Tomasza Szlendaka Architektonika romansu. Świetna książka. Ale do 
czego zmierzam - zadzwoniłam do Łukasza i powiedziałam, że widzę jego pytania na mapie. Tak naprawdę wchodzisz w mój świat - świat afazji, więc muszę go jakoś ułożyć w przestrzeni mojej głowy i na papierze, by również odbiorcy mogli go lepiej poznać.

\section{W ten sposób pomagasz też odbiorcy książki po prostu przejść przez krainę} Afazji.

Absolutnie, ponieważ bez takiej mapy jesteśmy jak przed abstrakcyjnym obrazem - albo mamy wolę i czas, by go obejrzeć, albo nie i idziemy dalej. Nie zależało mi również, by ten wywiad był w formie papierowej „Szumu”. To miała być osobna forma, dlatego zdecydowaliśmy się na internetową publikację. Okazało się, że miałam z tego ogromną przyjemność i zwykłą radochę z tworzenia. Z jednej strony jest więc litera, z drugiej - rozbudowana przestrzeń wizualna, graficzna. Zawsze widziałam pewne rzeczy bardziej graficznie niż malarsko, ponieważ nie jestem malarką, choć skończyłam malarstwo.

W trakcie pracy nad wywiadem opowiadałam o tym, czy są jakieś przyjemności w „czarnej dupie”, i powiedziałam, że brak - a dlaczego? Dlatego że był kiedyś taki zespół Brak w latach 8o., tzw. Nowa Fala, został stworzony w 1981, z tego, co pamiętam, i rozwiązany w 1984 roku. To taki niuans, ale czcionka, która znalazła się na okładce płyty tego zespołu, składała się niekompletnych, brakujących liter. Czcionka tych liter miała grubą, czerwoną oprawę. Kiedy zastanawiałam się, czy są jakieś przyjemności w „czarnej dupie", to stwierdziłam, że ich brakuje lub jest sam brak, absolutny - jak w latach 8o. Pomyślałam, żeby zrobić swoje brakujące litery - i od tego zaczęła się historia o brakującej czcionce. W mojej wersji nie ma grubej czarnej i czerwonej krechy, tylko są prawie niewidoczne kreski. Miesiąc po tym, jak zrobiliśmy wywiad, zadzwonił do mnie Andrzej Turowski i zapytał, czy nie chciałabym uczestniczyć w wystawie Rozdarcie i czy nie zrobiłabym czegoś w kontekście afazji. Na wystawie pojawił się wywiad, ale nie cały, ponieważ wystawa dotyczy tak naprawdę afazji, a nie książki, więc zrezygnowałam z kilku tekstów, które były w wywiadzie. Na początku mojej części wystawy pojawiają się pewne asymetryczne półki; widzisz je, kiedy wchodzisz do sali. Dlaczego? Dlatego, że my, Afazjanie, na początku odczuwamy świat sinusoidalnie, tzn. jednego dnia czujemy się prawie dobrze, a następnego dnia czujemy się absolutnie beznadziejnie. Kiedy rozmawialiśmy z Andrzejem o wystawie, zaproponował, żeby wykorzystać moje ćwiczenia logopedyczne i w ten sposób pokazać też „mięso” tej sytuacji. Właśnie podczas tych 
ćwiczeń zaczęłam bawić się literą. Od szlaczka zaczyna się cała ta historia, potem kolejne teksty wchodzą na ścianę - no i w ten sposób stworzyłam tekstowy świat afazji, który ma trochę katastroficzny posmak architektoniczny (śmiech).

Kiedy zaczęłam tworzyć tę czcionkę, było dla mnie jasne, że ona też musi być w pewien sposób brakująca, że z jednej strony jest linią, która jest, ale prawie jej nie widać, a z drugiej - musi być konstruktywistyczna. W myśleniu o tej wystawie to wszystko połączyło się w spójny komunikat - nawet z historią awangardy i alfabetem Strzemińskiego. Uświadomiłam sobie, że choć moja czcionka braku wizualnie jest brakująca, to musi dać komunikat, nie o to chodzi, żeby istniała jako „bezkomunikat”. [Karolina sięga po kartkę i długopis, i zapisuje neologizm „bezkomunikat”.]

\section{Zamierzasz nadal posługiwać się tą czcionką?}

Oczywiście. Bardzo mi zależy na tym, żeby można było tą czcionką pisać. Została skonstruowana w Illustratorze i muszę ją przeformatować w takim profesjonalnym programie typograficznym, który uwzględnia wszystkie parametry czcionki. Pomyślałam też o tym, żeby wysłać ją np. do DaFont to taki amerykański serwis z czcionkami.

Brakująca czcionka jest użyteczną brakującą czcionką. Mam teraz dużo na głowie i nie mogę zrobić wszystkiego od razu, ale najważniejsze, że dopięłam cały alfabet, bardzo mi zależało, żeby go dopiąć na wystawę. Pod alfabetem jest tekst napisany właśnie tą czcionką, żeby pokazać, że ten alfabet nie jest tylko wyobrażeniową formą rysunku, lecz także rzeczywistym i użytecznym komunikatem. Kiedy rehabilitowałam się poprzez zabawę surrealną formą językową, to w tym wszystkim zobaczyłam użyteczność pewnych ruchów. Moja książka jest nadrealną, futurystyczną opowieścią, w której jeżdżę ultramarynową wołgą po czymś, czego teoretycznie nie ma i jest bardzo subiektywne, ale z drugiej strony książka jest bardzo konkretnym komunikatem pod tytułem: teraz zobacz, otwórz ostatnią stronę i tam jest tak zwany paszport Afazjanina, możesz go użyć, przyda ci się. Jest też czcionka, której możesz używać. Na wystawie oprócz tekstów na ścianach była też informacja o stronie internetowej, taka mała aplikacja dedykowana, przekierowująca od tekstu ze ścian do miejsca, w którym robię swoją rzeczywistość tu i teraz - ta rzeczywistość to konferencja, dwa blogi, czyli tzw. „afazja”, która się zamieniła w „Kulturę i Neuronaukę”, oraz „literowanie obrazu”, czyli blog o poezji wizualnej. Bardzo mi zależało na tym, żeby nie ograniczać się do getta sztuki, żeby tak naprawdę wyjść z niego. Pomogła mi w tym moja choroba, udało mi się wyrwać z tego 
getta i po prostu zobaczyć rzeczywistość zupełnie inaczej. Nagle się okazuje, że tu jest ciekawiej, że sztuka jest zbyt obszerna i zbyt ciekawa, żeby zamykać ją w galeriach. Projekt Kultura i Neuronauka rozszerza myślenie o niej, ponieważ gdybym organizowała np. konferencję Sztuka i Neuronauka, to bym zamknęła się w tym getcie. Dlatego na wystawie pojawia się wirtualne przejście, aplikacja wchodzi w zupełnie inną przestrzeń.

\section{Czym jest brak, który pojawił się w Twojej części Rozdarcia? O jaki brak cho- dzi, brak czego? Czy w przestrzeni dialogu - jak określiłaś wystawę - ten brak może zostać zlikwidowany?}

Oczywiście, tylko przestrzeń dialogu niweluje brak, w którym znajduje się połowa Afazjan. Często zapominamy, że jesteśmy zwierzętami, podkreślam: zwie-rzę-ta-mi, naczelnymi, ale zwierzętami. Bez drugiego człowieka nie mamy zbyt wiele przyjemności - z kilku powodów i na wielu poziomach. Wielu Afazjan zamyka się w sobie i nie chce się otworzyć na drugiego człowieka, a przecież logika zdrowego myślenia mówi o tym, że to drugi człowiek da ci to poczucie istotności, o którym zapominasz, ponieważ masz intelektualne braki czy niepamięć tego, co tak naprawdę jest najistotniejsze. Wiesz, pamiętam, jak w pewnym momencie stwierdziłam, że właściwie to ja dobrze się mam pod chodnikową płytą, że w ogóle nie potrzebuję was wszystkich, ale jak wyszłam spod chodnikowej płyty, to nagle się okazało, że na zewnątrz jest dużo przyjemniej i można więcej. Samotność wpływa na rozwój wyobraźni, wtedy jesteś w stanie czytać poezję i rozumieć np. Peipera czy Czyżewskiego bardziej. Powtarzam sobie: „w pończosze istota jest” (śmiech). Uwielbiam tekst Twierdzenia Peipera. Więc siedzę sobie w samotności z Czyżewskim albo z Peiperem i mam się fajnie, rozmawiam sobie co jakiś czas z Watem, potem wychodzę na zewnątrz i czasem mogłabym porozmawiać np. o tym, co z tą pończochą jest - i do tego potrzebny jest drugi człowiek. Nadrzędna jest więc przestrzeń dialogu.

\section{Podstawowym brakiem w afazji jest więc brak ludzi?}

Tak. To, co mówiłam wcześniej, jest bardziej uniwersalne. Po wylewie odcięło mi drogi komunikacji - to jest jedna rzecz, z którą sobie w ten czy inny sposób poradziłam, nie całkowicie, ale poradziłam. Brak to także deficyt intelektu; dopadł on mnie i wielu innych podobnych mi ludzi. To mi bardzo doskwierało i doskwiera do dzisiaj. Dlaczego ciągle działam na literze? Dlatego, że język tak bardzo mnie kręci. A jednocześnie jedyny możliwy komunikat językowy, jaki mam, to komunikat w języku polskim, a wcześniej znałam angielski, 
francuski i rosyjski. Dzisiaj rozumiem angielski, ale nie jestem w stanie rozmawiać po angielsku, nie wspominając o francuskim, trochę rozumiem rosyjski, ale tylko trochę. Dla mnie przyjemność to jest właśnie obcowanie z tkanką intelektualną. I nagle jak tracisz tę możliwość, to przestajesz mieć przyjemności, więc jakie są przyjemności w „czarnej dupie”? Brak, dla mnie to jest absolutny brak. Czasem ktoś mi mówi: no przecież żyjesz. Świetnie, też się cieszę, że żyję, tylko że życie nie polega tylko na oddychaniu i na jedzeniu, i na oglądaniu słabych filmów. Wówczas boli mnie życie, zważywszy na to, że bardzo dużo czytałam przed wylewem. Po wylewie okazało się, że utraciłam największą i najważniejszą przyjemność, jaką posiadałam, czyli przyjemność czytania. Dzisiaj jest już trochę lepiej, ale oprócz poezji, co jestem w stanie czytać? Książki o mózgu (śmiech).

\section{One nie są łatwe przecież (śmiech).}

Ale mnie to kręci (śmiech). Mało tego, przez to, że poznałam swoją neurologię i wniknęłam w afazję nie tylko językowo, ale też neurologicznie, więcej rozumiem i mogę pomóc komuś innemu.

Takie doświadczenie sprawia, że ma się więcej empatii, która może przydać się przy czytaniu takich tekstów, jak teksty Peipera czy Wata. Wat przez całe życie borykał się z chorobą bólową, która miała przecież podłoże neurologiczne.

Peiper tak naprawdę pisał cały czas, tylko nie wiemy, co jest w tych zapiskach. One zostaną opublikowane za kilka lat, zmarł w 1969 roku, więc niedługo minie ten okres, kiedy są chronione prawem autorskim. Może to być zwykły bełkot, ale mogą to też być perełki ze świata neurologicznie pokiereszowanego człowieka. Peiper nie zwariował, on był po prostu chory neurologicznie. Jeśli zaczniemy rozumieć ten kontekst trochę inaczej, to dostrzeżemy wielowątkowość działań wielu artystów. My po prostu nie chcemy zastanowić się albo zatrzymać się na chwilę, by pomyśleć: a może to było trochę inaczej, niż mi się wydaje... To jest chyba kwestia naszej nieumiejętności wniknięcia w drugiego człowieka, a może po prostu braku edukacji.

Konferencja Kultura i Neuronauka ma właśnie edukacyjny cel. Chciałabym, żeby to były cykliczne spotkania, poświęcone nie tylko afazji czy SM, ale także np. depresji czy każdej innej niemożności neurologicznej, o której wielu z nas nie ma pojęcia. Jeżeli sami sobie nie poradzimy - my jako ludzie i jako społeczeństwo w jakimś fajnym dialogu - to nie będziemy się rozwijać jako społeczeństwo, będziemy po prostu ciągle gdzieś w latach 50. i będą nam 
tłumaczyć, że „władza wie, nauczy cię”. A my przecież potrafimy radzić sobie na wielu poziomach i właśnie dlatego wymyśliłam konferencję.

\section{Można powiedzieć, że podstawowy brak, jaki dotyka naszego społeczeń- stwa, to właśnie brak tej przestrzeni dialogu.}

Tak. My czasem nie chcemy otworzyć się na ten dialog, dlatego konferencja jest dialogowa. Jest ona tak skonstruowana, że w jednej przestrzeni znajdują się dwie mównice, nie ma np. stołu zielonego, suknem przybranego (śmiech). Wykorzystuję po prostu dwie przezroczyste mównice, na tym samym poziomie. Najpierw mówi jedna osoba, kolejna osoba mówi przez 20 minut, a przez następne 20 minut nadawca i słuchacz mogą rozmawiać, przez co jesteśmy w tzw. dialogu, w przestrzeni dialogu. To wszystko tak dobrze się sprawdziło! Podczas pierwszej konferencji opowiadałam o afazji, o książce tak naprawdę, a pani profesor Małgorzata Kossut jako biolog, która zajmuje się plastyką mózgu, mówiła z perspektywy teoretycznej - ja mówiłam z perspektywy praktycznej, gdzie jest ta plastyka mózgu, od czego się zaczyna. Zaczyna się od chęci, która bardzo często zaczyna się od tzw. tabletki szczęścia, czyli psychotropu. Wielu z nas, Afazjan, ma depresję. Depresja, udar, wylew kiereszują ci całą sferę wewnętrzną. Leki poudarowe i antydepresanty powodują, że ci się chce, zaczyna się chęć, dodatkowo świat nabiera kolorów. Te leki powodują też, że ciśnienie wewnątrzczaszkowe normuje się, a jak się normuje, jest mniejsze prawdopodobieństwo kolejnego udaru. Dlatego tak bardzo ważne jest, żeby ludzie po udarach mieli świadomość, że lepiej brać te leki, ponieważ dzięki temu będzie im się dłużej i lepiej żyło, nie będą mieli kolejnego wybuchu mózgu. Tu nie chodzi o to, czy ty masz depresję, czy jej nie masz, to jest efekt uboczny, który ci się przytrafia i tylko warto mieć tego świadomość. Tyle. Jak nie chcesz brać, to nie rób tego, tylko pamiętaj, że jesteś jednostką społeczną, a to znaczy, że twoja żona, matka, córka mierzy się również z twoją niepełnosprawnością. Leki wszystko normują, nie masz np. takiego „wkurwu” na niemożność.

Jak zmieniło się twoje postrzeganie umysłu i mózgu jako organu po doświadczeniu afazji? Użyłaś wcześniej określenia, że mózg jest Twoim najlepszym mięśniem.

Nasz mózg jest tym, co uświadamia mi ewolucję ludzką. Gdybym miała wylew w latach 70., to bym nie przeżyła - wszyscy mi o tym mówią. Miałam wylew w XXI wieku, mogli mnie zoperować i choć dostałam drugiego udaru, to byłam w stanie zrehabilitować się do tego stopnia, że mogę z Tobą 
rozmawiać. I nagle okazuje się, że ewolucja dzieje się teraz, widzę ją na swoim przykładzie; nie jestem kimś wyjątkowym, jestem tylko przykładem, jestem jednym z nas wszystkich. Tylko przez pewien przypadek doświadczyłam, jakim jesteśmy genetycznym fenomenem jako ludzkość. Nie dość, że byliśmy w stanie się rozwinąć, stworzyć aparatury zdolne wejść w nasz mózg, naprawić go, to jeszcze sami potrafimy się zrehabilitować i mamy do tego odpowiednie narzędzia, czyli np. książki, komputery, aplikacje. To wszystko jest w nas, ponieważ to wymyśliliśmy. Bez tego wszystkiego byłabym warzywem albo po prostu bym nie żyła. Trzeba być świadomym możliwości ludzkich. Pamiętam jak jakieś cztery lata temu dostałam taką książkę Łurii [Karolina zdejmuje z półki tę książkę; chodzi o Świat utracony i odzyskany. Historię pewnego zranienia Aleksandra Łurii]. Świetna książka, pożyczam Ci ją. Przeczytaj, bo to bardzo, bardzo ciekawa rzecz. Jak dostałam tę książkę, już wtedy pisałam bloga. Książka opisuje historię człowieka, który był ranny w głowę w trakcie wojny, miał głęboką afazję i zaczął po prostu o tym pisać. To były lata 50. czy 6o., musiał to wszystko pisać na papierze. Ja żyję w XXI wieku, piszę na komputerze i jednocześnie mogę to opublikować na blogu. Czasem ktoś mi mówi, że nie chodzi tylko o technikę, ale technika to przecież nasz mózg, ponieważ to mózg dał nam możliwość wyobrażenia, jak może wyglądać maszyna licząca, która będzie nam ułatwiała komunikację ze światem. A zaczęło się od prostego algorytmu...

\section{... który też my wymyśliliśmy.}

No właśnie! Trzeba więc myśleć nie tylko o biologicznych aspektach naszej rzeczywistości, ponieważ wówczas ograniczamy się do getta medycznego. Ale żebym mogła dojść do tego momentu, w którym jestem teraz, musiałam przejść całą tę drogę i radzić sobie sama. Tak naprawdę świat nie interesuje się takimi przypadkami jak my. Dlaczego ciągle słyszę: a co to jest afazja? Trzecia z kolei przyczyna śmierci to udar, a wy nie wiecie, co to jest afazja? O, babcia miała, nie mogła mówić. Udar jest chorobą cywilizacyjną, a zatem każdy może mieć udar, nie tylko twoja babcia; ja też miałam udar i próbuję ci coś wytłumaczyć. Masz nadciśnienie, ponieważ źle się odżywiasz, więc możesz mieć udar. Oczywiście, to wszystko jest też związane z tym, że są ewidentne braki w edukacji. Ludzie zaszczepiają się przeciwko różnym chorobom, ale nie sprawdzają mózgu. Wystarczy zrobić zwykłe EEG albo Dopplera - takie proste badanie. Ja miałam genetycznego tętniaka, a zatem wystarczyło sprawdzić, czy w moim mózgu nic się nie dzieje, i nie byłoby żadnego problemu. Trzeba po prostu o tym wszystkim mówić, trzeba się informować nawzajem, stąd konferencja. Jak my sobie nie poradzimy, to kto nam poradzi? 


\section{Skoro już wspomniałaś o konferencji Kultura i Neuronauka, to zatrzymajmy się przy tym temacie. Opowiesz na czym polega ten projekt?}

Kultura i Neuronauka jest projektem społecznym, nastawionym na wiedzę, edukacyjnym i pokazującym, że wiele tematów związanych z naszą niesprawnością neurologiczną jest opisywanych nie tylko w medycynie, ale również w malarstwie, rzeźbie, poezji, literaturze, filmie. Właśnie dlatego miejscem konferencji jest Zachęta, tam ludzie bardzo dobrze rozumieją istotę i wagę problemu. Pomyślałam, że trzeba coś zmienić, uruchomić - no i faktycznie uruchomiło się wiele osób, zupełnie w różnych rejestrach. Nie można opierać się tylko na mechanice, zważywszy na to, że mechanika dotyczy mózgu, a mózg to my. Jest jeszcze sfera mentalna, psychologiczna. Oczywiście niektórzy to rozumieją, ale niektórzy nie, a szkoda. Kiedy sobie to wszystko uświadomiłam, wiedziałam, że to może zadziałać, nie tylko w moim myśleniu. Skoro jestem w dobrej formie, mam możliwości i energię, to mogę komuś pomóc. I nagle się okazuje, że ta energia działa. Hanna Wróblewska, dyrektorka Zachęty, powiedziała: dobrze, zróbmy to, bo to fajny projekt. Po czym rozmawiam z Marcinem Grynbergiem z Obywateli Nauki i on mówi: świetnie, to my będziemy twoimi partnerami. Wszystko w super pozytywny sposób działa. Spotykam się z Neuropozytywnymi, z fundacją od SM i wszyscy mówią, że w to wchodzą. Jadę do Wrocławia, opowiadam im o idei i zyskuję kolejnego partnera konferencji. Wszyscy, mam wrażenie, mają pełną świadomość wagi projektu. Podczas konferencji czegoś się uczę, nie mogę dobrze czytać, więc słucham. W tej mojej cwaniarskości jest jeszcze coś innego. Osoby chore czasem nie mają tyle energii, a zatem pomóżmy sobie nawzajem. Ja coś potrafię, ty potrafisz coś innego, więc zróbmy coś razem. W ten sposób konferencja się rozwija. Dwa lata temu trwała jeden dzień, w tym będzie trzydniowa. Odbędą się warsztaty, dwa dni wykładów, tak jak mówiłam, na zasadzie dialogu - na jednej scenie dwie mównice, a trzeci mówca to słuchacz - to bardzo ważne.

Neuropozytywni, o których wspomniałam wcześniej, są moimi partnerami przy konferencji o SM i właśnie zaczęli wydawać „Świat Mózgu”. Będą oni, Iza Walicka, razem z Noahem Huttonem z The Beautiful Brain? The Beautiful Brain to projekt, który stworzyła trójka ludzi z Nowego Yorku. Noah jest kuratorem, robi wystawy i dzięki tym wystawom promuje

7 Piękny umysł (The Beautiful Brain) to niezależny blog o relacjach między neuronauką i sztuką, istniejący od 2009 roku. Prowadzą go: Noah Hutton, Ben Ehrlich i Samuel D. McDougle. Strona internetowa projektu: http://thebeautifulbrain.com/ (1.09.2016). 
wiedzę o mózgu; kolejna osoba to neuropsycholog i jest jeszcze trzecia osoba - pisarz. Ich projekt dotyczy rozumienia mózgu przez sztukę. Iza proponuje nowe myślenie o mózgu, które uwzględnia medytację. Zrobiła np. wywiad z Richardem Davidsonem, który jest psychiatrą, ale jednocześnie psychologiem, i bada plastykę mózgu mnichów buddyjskich. Bo czym tak naprawdę jest sztuka? Jest otarciem się o duchowość, jak mówi Sontag. Świadoma sztuka ociera się o duchowość, w szczególności, jeżeli wynika z takich trudności, z jakimi zmaga się na przykład Iveta Pilařová, która w wieku 18 lat zaczęła chorować na stwardnienie rozsiane. Dzisiaj ma prawie czterdziestkę i jest niepełnosprawną dziewczyną, a tworzy bardzo ciekawe rzeczy.

\section{Opowiesz dolkadniej o konferencji o SM, którą planujesz?}

Będzie w bardzo podobny sposób skonstruowana jak konferencja o afazji, czyli przy jednej mównicy pojawi się naukowiec lub neuronaukowiec lub osoba, która zajmuje się propagowaniem wiedzy o mózgu, a przy drugiej - człowiek, który zajmuje się szeroko rozumianą kulturą i który opowiada o niemożności, tylko w innym „dialekcie”. Jak wspomniałam wyżej, w tym roku będzie np. dialog między Noahem z The Beautiful Brain i Izą Walicką z Neuropozytywnych, która choruje na SM od wielu lat, jest już na wózku, ma agresywną formę choroby, ale aktywnie propaguje wiedzę o mózgu. I tu jest właśnie to clou - jeden i drugi gość promuje wiedzę o mózgu, tylko w inny sposób. On tworzy serwis informujący o mózgu przez sztukę, a ona robi dwie gazety - jedna to „Świat Mózgu”, druga to „Neuropozytywni”. „Neuropozytywni” to gazeta stricte skierowana do ludzi chorych na SM. „Świat Mózgu” chyba od sierpnia jest już w Empiku

\section{Bardzo mi się podoba tytuł tej gazety - mózg jest jak świat po prostu.}

Dokładnie tak. Iza jest bardzo pozytywną kobietą. Ostatnio zadzwoniła do mnie i zapytała, czy mogłabym napisać kilka słów o sztuce niepełnosprawnych, czy w ogóle jest taka figura jak „sztuka osób niepełnosprawnych”. Kiedy zaczęłam o tym myśleć, uświadomiłam sobie, że rzeczywiście jest coś takiego jak sztuka niepełnosprawnych, tylko wszystko zależy od tego, czy osoba, która zajmuje się sztuką, ma pełną świadomość, jakiego odbiorcy potrzebuje - to jedna rzecz. Druga rzecz, sztuka musi być na początku dobra, nieważne czy opowiada o niepełnosprawności, czy też nie. Obiektywnie po prostu musi być dobra, a czy robisz sztukę nogą, zębem czy czymkolwiek innym, to nieważne. Podstawowa kwestia to, z jakim odbiorcą chcesz się komunikować. 
Pamiętam, jak Iza zapytała mnie: nie masz wrażenia, że jesteśmy na granicy arteterapii? Odpowiedziałam, że nie, że wszystko zależy od tego, o czym chcesz mówić. Jeżeli masz pełną świadomość tego, kim jesteś - jestem artystą, jestem niepełnosprawny - masz pełną świadomość historii sztuki, filozofii i wszystkich innych pobocznych dziedzin, które wpływają na sztukę, i efekt twojej pracy przybiera postać obrazu, tekstu, czegokolwiek - no to istnieje również sztuka niepełnosprawnych. Można powiedzieć, że Wołga przez Afazje to książka osoby niepełnosprawnej. A to, czy tobie książka się podoba czy nie, to już jest kwestia gustu. Definicje to jedna rzecz, a odbiór sztuki to już druga rzecz; jedna rzecz to arteterapia, druga rzecz to sztuka, to, co lubisz i to, czego nie lubisz - to są zupełnie inne sprawy. Podczas rozmowy z Izą ${ }^{8}$ uświadomiłam sobie, jak istotne jest, by powiedzieć o tym na konferencji. Ludzie tak naprawdę nie do końca rozumieją takie niuanse, dlatego konferencja ma przede wszystkim formę edukacyjną.

Kiedy zaczęłam myśleć o SM, zauważyłam, że dysfunkcje poznawcze w przypadku tej choroby są podobne do afazji, ale pojawiają się też diametralne różnice. Zrozumiałam, że kiedy chorujesz na SM, tak naprawdę zostajesz osobą niesprawną do końca życia, absolutnie niesprawną i tak naprawdę coraz bardziej niesprawną, a zatem musisz zrozumieć, jaka jest twoja niesprawność, jak się rozwinąć przez swoją niepełnosprawność i jak żyć z nią lub obok niej. Kto będzie w takim razie centrum konferencji? Wspomniana wyżej Iveta Pilařowá, która jest czeską rzeźbiarką, tworzącą świetne figurki. Jestem zachwycona jej sztuką. Ma bardzo agresywną formę SM i ona robi sztukę jako osoba niepełnosprawna, jest w nurcie sztuki niepełnosprawnych, robi sztukę o niemożności. W ten sposób przybliża świat niepełnosprawnych i to jest dla mnie szalenie ważne.

To był zawsze taki świat obok, trochę wyłączony, zawsze jakoś na marginesie. Tak, ale to dla mnie zupełnie absurdalne. Iveta zgodziła się i bardzo się z tego powodu cieszę, ponieważ jest cudowną osobą, a bardzo mi zależało na tym, żeby konferencja odbywała się w bardzo ludzkiej i przyjaznej atmosferze. Odbędzie się też pokaz jej prac. I to jest właśnie to "mięso", na którym mi zależało. Zaproponowałam, żeby Iveta weszła w dialog z Richardem Davidsonem. Jeśli Davidson się nie zgodzi, to mam jeszcze jedną propozycję. Chodzi o Patricię Churchland, która napisała filozoficzną książkę pod

8 Wywiad został opublikowany w "Świecie Mózgu” i na blogu projektu Kultura i Neuronauka (afazja.blogspot.com). 
tytułem Moralność mózgu. Przedmowę do tej książki napisał Mateusz Hohol. Z kolei mąż autorki - Paul Churchland - napisał książkę o duchowości mózgu?.

W następnym dialogu, o którym myślę, wzięłaby udział Monika Morawska, która jest doktorem na ASP w Warszawie, zajmuje się teorią sztuki i filozofią w sztuce, głównie fenomenologią. W swojej pracy naukowej ona dotyka pewnych sensów, o których będziemy rozmawiać na konferencji. W dialogu z nią będzie - mam nadzieję, że się zgodzi, bo poprzednio nie mógł - Włodzisław Duch, kognitywista. Taki dialog na otwarciu znacznie rozszerzyłby myślenie o tym, na jakiej płaszczyźnie teraz jesteśmy i z jakiej perspektywy możemy spoglądać na nasz umysł. Bardzo mi też zależy na dialogu inżyniera neurologicznego i pisarza-futurysty. Chciałabym mieć takiego Lema, ale skoro nie ma Lema, to pomyślałam o Dukaju.

Bardzo mi zależy na zaproszeniu inżyniera, który tworzy usprawnienia dla fizyczności chorych na SM, na przykład kiedy nie możesz chodzić, to masz taką specjalną usprawniającą nakładkę na nogę i nie musisz jeszcze używać wózka. Taka dziwna konstrukcja przypomina trochę przedwojenny futuryzm, dlatego pomyślałam właśnie o pisarzu, który byłby zainteresowany tym zjawiskiem.

\section{Na koniec chciałabym zapytać Cię o komunikację wizualną. Co sądzisz o tym zjawisku? Czy taka komunikacja ma szansę zastąpić tę słowną? Obecnie one w pewien sposób współistnieją. Jakie jest znaczenie komunikacji wizualnej dla osób neurologicznie niesprawnych?}

Współistnieją i będą współistniały cały czas. Uważam, że musi być przestrzeń dialogu między nimi, ponieważ bez niej niewiele nam się uda, zważywszy na to, że żyjemy w przestrzeni coraz bardziej wizualnej. Przestajemy czytać i opieramy się na tekście, ale nie linearnym, tylko właśnie na tekście wizualnym, który czasem jest hasłowy. To taka charakterystyczna cecha naszych czasów. Nie mówię, czy to dobrze, czy źle. W niektórych przypadkach bardzo źle, w niektórych przypadkach super, ponieważ ten inny rodzaj komunikacji otwiera przestrzeń możliwości. Ale bez powiązania tych dwóch dziedzin nic nam się nie uda, moim zdaniem. Dlatego wzięłam udział w warsztatach o komunikacji wizualnej.

9 P.M. Churchland Mechanizm rozumu, siedlisko duszy. Filozoficzna podróż w głąb mózgu, przeł. Z. Karaś, Aletheia, Warszawa 2002. 


\section{Na czym one polegały?}

Cała konferencja była zorganizowana przez Ewę Satalecką w Centrum Nauki Kopernik w dniach 9-13 grudnia 2014 roku i miała za zadanie pokazać, czym jest komunikacja wizualna. Odbyły się np. warsztaty typograficzne czy warsztaty pokazujące możliwości komunikacji wizualnej w kwestii zwiększenia informacyjnej dialogowości w przestrzeni miasta. Dla osób niepełnosprawnych miejska strefa komunikacyjna to jest po prostu jakaś potwora. Warsztaty, w których uczestniczyłam z Marcinem Wichrowskim, były poświęcone aplikacjom dla Afazjan. Marcin jako programista stworzył jedną prototypową aplikację, dzisiaj ta aplikacja jest już dostępna. Zaproponował mi, żebym wzięła udział w tych warsztatach jako osoba, która z jednej strony rozumie wizualnie, z drugiej strony, która przeżyła to, co przeżyła. No i stworzyliśmy takie trzydniowe warsztaty, w trakcie których powstały cztery prototypy aplikacji dla Afazjan, ułatwiających życie na różnych poziomach świadomości. Jedna z aplikacji - aplikacja Magdy Żołądek, która bardzo mi się spodobała - dotyczyła komunikacji zaraz po wylewie lub udarze, czyli w momencie, kiedy nie jesteś w stanie nic zrobić, nic napisać ani nawet się napić. I taka aplikacja ułatwiałaby np. przekazanie informacji: „chce wody”. Wystarczy ręką przesunąć po ekranie i wskazać szklankę. Osobom po udarze czy wylewie strasznie chce się pić i nieważne, czy to jest udar prawostronny czy lewostronny, po prostu mamy absolutne suchoty i należy nas nawadniać, a panie pielęgniarki często o tym zapominają. Bardzo się cieszę, że jest XXI wiek i są telefony i aplikacje dające możliwości osobom, które są bardzo, bardzo chore. Dlatego taka współpraca różnych osób, reprezentujących różne dziedziny wiedzy, jest niezmiernie ważna; trzeba po prostu spotkać się w jednym miejscu i porozmawiać.

\section{Dzięluję za rozmowę.}




\section{Abstract}

\section{Klaudia Muca}

JAGIELLONIAN UNIVERSITY (CRACOW)

In the Stocking the Essence Is...: Interview with Karolina Wiktor

This interview touches on the life and work of visual artist Karolina Wiktor and her exploration of her personal experience of aphasia. Wiktor describes aphasia as 'an explosion of the brain' or a'disfunction of the intellect'. This explosion results in an inability to communicate, to recall memories or to express emotions through language. The author Wołgą przez Afazję [Down the Volga through Aphasia] has successfully recovered the ability to express herself and her experience. In her work she uses a variety of artistic media, creating visual poetry as well as artistic installation. She has also produced what she calls an alphabet of the missing font - a new type of font whose form expresses an aspect of her experience of aphasia.

\section{Keywords}

aphasia, communication, brain, disability, lack, art, poetry, emotions, dialogue 